\title{
Micro-morphological and morphometric characters analysis of Silica Bodies (SB) on leaf epidermal cells of five selected taxa in the Sub- family panicoideae based on Analytical Microscopy (AM): A systematic approach
}

Shilpa Dinda, Souradut Ray and Amal kumar Mondal*

Plant Taxonomy, Biosystematics and Molecular Taxonomy Laboratory, UGS-DRS-SAP Department, Department of Botany and Forestry, Vidyasaga University, Midnapore-721102, West Bengal, India.

Received: November 12, 2016; Revised: November 24 2016; Accepted: November 26, 2016

\begin{abstract}
Plants have unique capability to deposit silicon (si) with and between the cells and thus creating casts of the cells commonly known as silica bodies (plant stones). Silicon are very abundantly present only in the family Poaceae among monocotyledon. These silica bodies contain the composition of silicon to form different structural diversity of stone cells like long or short bar with rounded or semi rounded spheres dumbbell shaped, sinuous elongated rectangular, narrow elliptical rectangular, randle, polylobed and cross shaped etc. Light (LM), Polarized (PM), Fluorescence Microscopy (FM) and Scanning Electron Microscope (SEM) were used for better micro-morphological study. These micro characters might be applied numerically by UPGMA method to solve different taxonomic problems within familial, generic and species level and compared to other systematics.
\end{abstract}

Key words: Silica bodies; diversity; numerical analysis; phylogeny; dendogram

\section{Introduction}

Phytoliths (from Greek "plant stone") are rigid, microscopic structures made of silica, found in some plant tissues and persisting after the decay of the plant. These plants take up silica from the soil, whereupon it is deposited within different intracellular and extracellular structures of the plant. Phytoliths come in varying shapes and sizes. Although some use "phytolith" to refer to all mineral secretions by plants, it more commonly refers to siliceous plant remains. First, soluble silica, also called monosilicic acid, is taken up from the soil when plant roots absorb groundwater. From there, it is carried to other plant organs by the xylem. By an unknown mechanism, which appears to be linked to genetics and metabolism, some of the silica is then laid down in the plant as silicon dioxide. This biological mechanism does not appear to be limited to specific plant structures, as some plants have been found with silica in their reproductive and sub-surface organs. Phytoliths are microscopic silica bodies that precipitate in or between cells of living plant tissues, but are especially abundant, diverse, and distinctive in the grass family Poaceae. Many taxa in Poaceae are characterized by phytoliths with specific morphological characteristics, hence their taxonomic significance. Phytoliths are released from plant tissues when they are decayed, burned, or digested. Released phytoliths thus become microfossils of the plants that produce them. Phytolith morphology and taxonomy, as well as the application of phytolith analysis to archaeological and paleo-environmental research.
There is still debate in the scientific community as to why plants form phytoliths, and whether silica should be considered an essential nutrient for plants. Studies that have grown plants in silica-free environments have typically found that plants lacking silica in the environment do not grow as well. For example, the stems of certain plants will collapse when grown in soil lacking silica. In many cases, phytoliths appear to lend structure and support to the plant, much like the spicules in sponges and leather corals. Phytoliths may also provide plants with protection. These rigid silica structures help to make plants more difficult to consume and digest, lending the plant's tissues a grainy or prickly texture. Phytoliths also appear to provide physiologic benefits. Experimental studies have shown that the silicon dioxide in phytoliths may help to alleviate the damaging effects of toxic heavy metals, such as aluminum. The outermost dermal layer is called epidermis. It is one layer thick and covered with waxy film. The epidermal cell is somewhat irregular in outline usually varying in shape size and arrangement, which is a important tool for taxonomic study. Most plants have non-protoplasmic inclusions in some of their cells, such as calcium oxalate crystals, starch grains, tannins and silica bodies. In some groups the presence of such cell inclusions may represent a potentially significant taxonomic character. For example, calcium oxalate styloids are a characteristic feature of the family Iridaceae (Goldblatt et al., 1984; Rudall,1994); also crystal

\section{${ }^{*}$ Corresponding Author:}

Prof. Amal kumar Mondal,

Professor in Botany \& HOD \& Coordinator UGC-DRS-SAP,

Department of Botany \& Forestry,

Plant Taxonomy, Biosystematics and Molecular Taxonomy Laboratory,

Vidyasagar University,

Midnapore-721 102, West Bengal, India.

E-mail: amalcaebotvu@gmail.com 
druses are largely restricted to some basal monocotyledons: Acorus and Alismatales (Prychid and Rudall, 1999, 2000; Keating, 2003). Silica bodies of various shapes and sizes occur in leaves of several groups of monocotyledons, always in well-defined tissues. This article reviews the presence, form and distribution pattern of silica bodies in one large group of flowering plants, the monocotyledons, in the context of both a historical review and a phylogenetic framework. Silica in the form of bodies or particles deposited within or on cells, as distinct from silica incorporated in cell walls or completely filling hairs and oter cells, occurs in certain groups throughout the plant kingdom, including, Selaginella (Bienfait et al., 1985; Le Coq et al., 1991), Equisetum (Laroche,1968; Kaufman et al., 1971), some ferns (Rolleri et al., 1987) and to a small extent gymnosperm leaves and wood (Jiang and Zhou, 1989; Sangster et al., 1997), as well as some angiosperm families. Piper no (1988) listed pteridophytes, gymnosperms and angiosperms that contain silica bodies, with notes on their abundance and position. Silica bodies may be found in all plant parts, although less commonly in roots. In wood they are sometimes termed "silica grains" and are characteristically situated in the ray or axial parenchyma cells of certain genera in about 55 dicot families. In reproductive parts they may be different in shape from those in vegetative parts, as Piperno (1989) showed in many tropical angiosperms. Recent systematic analysis of monocotyledons that have considered this character have recorded only presence or absence of silica bodies. However, their form and position, which are not greatly influenced by environmental factors but are clearly genetically controlled, may also have considerable systematic potential.

\section{Materials and Methods}

The five plants (leaf) Digitaria ciliaris Retz., Echinochloa colonum L., Heteropogon contortus L., Paspalidium flavidum Retz. and Saccharum officinarum L. are mostly collected from the study area of Paschim Midnapore (Vidyasagar University Campus) West Bengal, India which may be authenticated by Global Positioning System GPS (Garmin- 10) and it was done in the month from February to May. (Fig.1)

The leaves are taken and immersed in that FAA solution for at least $24 \mathrm{hrs}$ and next day peeled the leaf and preparing the permanent slide. After preparing slides were observed under light microscope (LM), polarized microscope (PM), fluorescence microscope (FM) and scanning electron microscope (SEM) for detailed analysis. Camera Lucida drawing and the dendrogram is constructed by the method of UPGMA analysis (Sokal and Sneath).

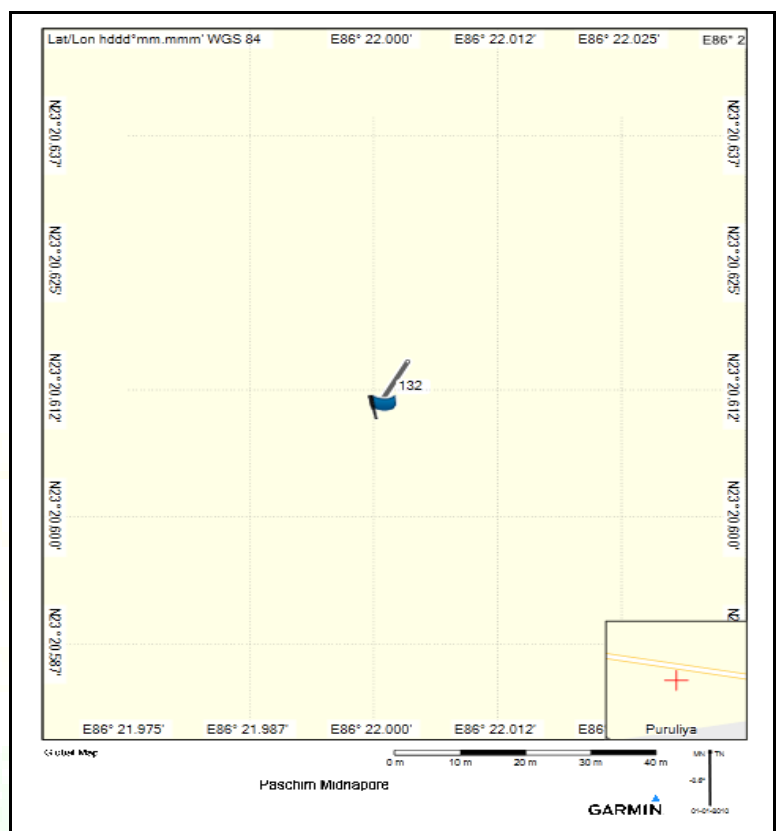

Fig. 1: Authenticated by Global Positioning System (GPS) of Paschim Medinipur Disdrict (Vidyasagar University Campus).

\section{Results}

A. Morphological description in five sclected Plant Taxa

Digitaria ciliaris Retz. (Fig.2): Annual. Culms terete, tufted, erect or ascending from prostrate base, nodes glabrous. Leaf sheath compressed, glabrous, hispid or hairy, ligule membranous. Leaf blade flat liner, glabrous or hispid, bulbous based hairs at mouth, apex acuminate. Racemes 2-9, subdigitate, rhachis straight, triquetrous, winged. pedicels 2 -nate, one very short, other upto $2 \mathrm{~mm}$ long. Spikelets appressed, narrowly elliptic, glabrous when young with spreading white tomentum at maturity. Lower glume absent or minute, hyaline, orbicular. Upper glume membranous, narrowly ovate, 3-nerved, finely hairy between the marginal nerves and along the margins, apex acute. Palea absent or very minute. Upper lemma subcoriaceous, narrowly ovate, 3 -nerved, margins inflexed, brownish at maturity, apex acuminate. Palea subcoriaceous, narrowly ovate, margins inflexed, apex acuminate. Lodicules 2, stamens 3. Caryopsis elliptic.

Flowering \& Fruiting period - August to December

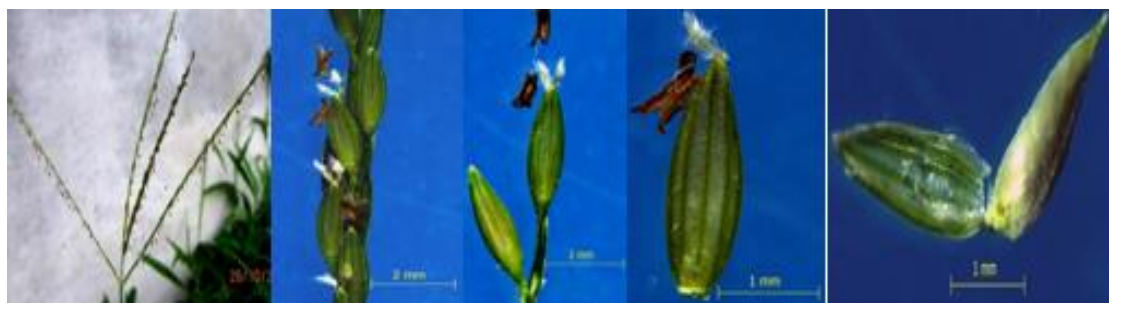

Fig. 2: Different part of inflorescence of Digitaria ciliaris under Stereozoom Microscope. 
Echinochloa colonum L. (Fig.3): Annual. Culms terete, erect, decumbent or short creeping below, glabrous, simple of branched, nodes glabrous. Leaf blade flat, linear ovate, glabrous, margins scaberulous, apex acuminate. Racemes pyramidal, spikes suberect, usually distant, rachis stout, angular, scaberulous on angles. Pedicels short, unequal, scaberulous. Spikelets paired, broadly ovate, hispidulous or scabrid. Lower glume membranous, broadly ovate, 3-nerved, clasping at base, scaberulous on the nerves, apex cuspidate. Upper glume membranous, broadly elliptic, 5-7 nerved, scaberulous on nerves, apex acute to cuspidate. Lower lemma broadly ovate, 5 -nerved, scabrid on nerves, apex acute to cuspidate. Palea hyaline, elliptic, 2-nerved, 2-keeled, margins inflexed in the lower half. Upper lemma chartaceous, broadly elliptic, 5-nerved, apex acute. Palea chartaceous, broadly elliptic, 2-nerved, margins inflexed with basal flaps, apex acute. Lodicules 2. Stamens 3. Caryopsis broadly elliptic to orbicular.

Flowering \& Fruiting period - July to February

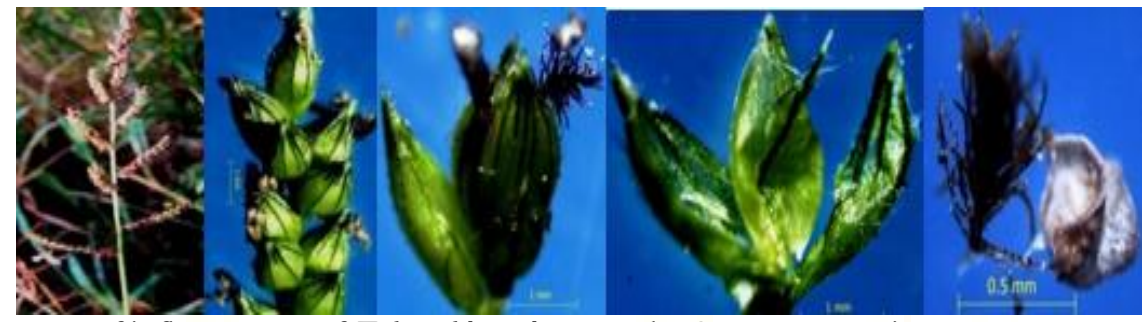

Fig. 3: Different part of inflorescence of Echinochloa colonum under Stereozoom Microscope.

Heteropogon conteortus L. (Fig.4): Annual or perennial. Culms tufted, erect or geniculate at base, simple or springly branched, glabrous, nodes globrus. Leaf sheath compressed, glabrous or sparsely hariy, ligule a rim of haris. Leaf blade flat, linear, glabrous or hariy, margins scaberulous, apex obtuse or auminate. Raceme solitary, terminating to culms and brancehes. With lower awnless, homogamous spikelets pairs and upper awned heterogamous. Joints glabrous. Hermaphrodite sessile spikelets linear to narrowly oblong, awned callus pungent, bearded with brown hairs. Lower glume coriaceous, linear to narrowly, scaberulous on dorsal surface, margins inflexed, many nerved, apex obtuse or rounded, upper glume coriaceous, linear, grooved on dorsal side, hariy along the groove, margins inflexed, 3-nerved, apex obtus.
Lower lemma hyaline, linear, nerveless, apex rounded. Palea absent. Upper lemma hyaline to base of geniculate awn, geniculate awn. Palea absent lodicules 2. Stamens 3. Caryopsis cylindric. Pedicels glabrous. Pedicelled spikelets linear elliptic, unawned. Lower glume subcoriaceous, narrowly elliptic, marigns inflexed, 9-11 nerved, hispid with tubercle based hairs, 2-keeled, apex acute. Upper glume membranous, linear ovate, 5-nerved, sparsely hairy, apex acute. Lower lemma empty, hyaline, narrowly obovate, margins inflexed, 1-nerved, margins ciliate, apex subacute. Palea minute or absent, hyaline, ovate, nerveless. Upper lemma hyaline, narrowly obovate, 1-nerved, margins ciliate, apex acute to acuminate. palea absent. Lodicules. 2. Stamens3.

Flowering \& Fruiting period - July to January

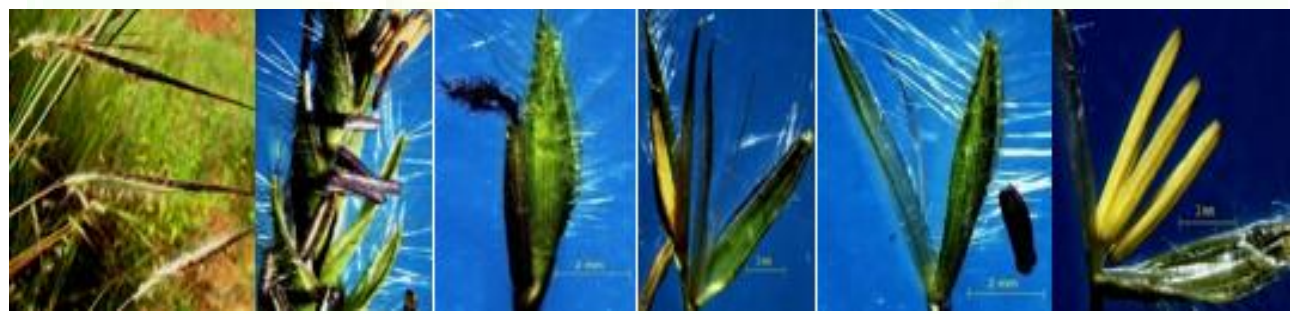

Fig. 4: Different part of inflorescence of Heteropogon contortus under Stereozoom Microscope.

Paspalidium flavidum Retz. (Fig.5): Annual or perennial. Culms compressed, erect or decumbent, nodes glabrous. Leaf sheath compressed, keeled, glabrous, membranous. Leaf blade flat or inrolled, linear to linear ovate, glabrous, apex acute. Spikes 3-10, sessile, distant, erect or ascending, $1-2 \mathrm{~cm}$ long, alternate, shorter than internodes, rachis flexuous, flattened, axis produced beyond spikelet. Spikelets biseriate, glabrous. Lower glume membranous, broadly elliptic to orbicular, glabrous, 3-nerved, apex rounded. Upper glume membranous, broadly ovate elliptic, glabrous, 7-nerved, apex obtuse. Lower lemma membranous, broadly elliptic-ovate, glabrous, 5-7-nerved, apex subacute. Palea hyaline, broadly elliptic-ovate, 2-keeled, 2-nerved, apex subacute. Lodicules 2. Stamens 3. Upper lemma coriaceous, broadly ovate, glabrous, rugose, margins inflexed, 3-5-nerved, apex acute. Palea coriaceous, ovate, glabrous, rugose on dorsal side, margin inflexed, 2nerved, acute. Lodicules 2. Stamens 3, Caryopsis, broadly ovate.

Flowering \& Fruiting period -August to October 


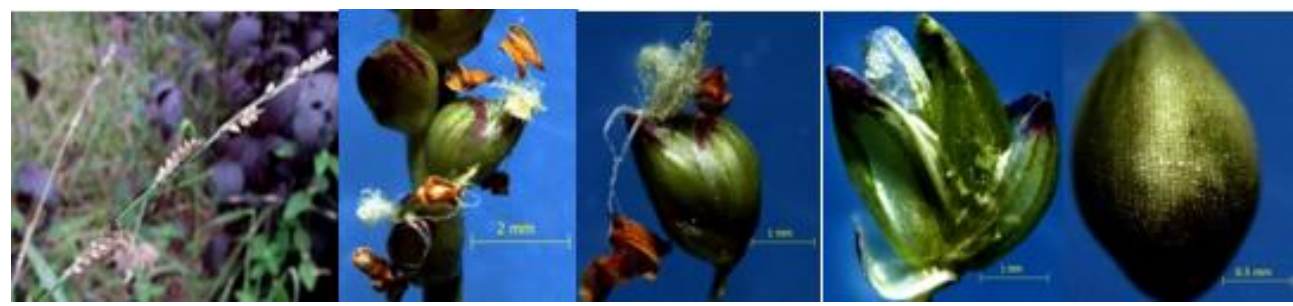

Fig.5: Different part of inflorescence of Paspalidium flavidum under Stereozoom Microscope

Saccharum officinarum: Perennial. Culms stout, erect, cylindric, many noded. Leaves linear, drooping. Panicles large, pyramidal, spreading, spikelets with silky white hairs.

Flowering \& Fruiting period - October to December

B. Micro-morphological description in five plant taxa

In this study it is found that Digitaria ciliaris have one type of stone cells, bilobate with short bar between semi rounded sphere. The dumbbell shaped silica bodies are found over the vascular bundle. The spheres of the dumbbell may be concave where they fit against the cells in the same row and they are distantly placed. Rectangular type of silica bodies are found in different position of the epidermal cell and scatteredly (Fig.6).

Echinochloa colonum consist of one type of stone cells, bilobate and complex bilobate form. The bilobate and complex bilobate shaped silica bodies are found one or two rows over the vascular bundle, they fit against the cells in the same row and they are compactly arranged (Fig.7). Heteropogon conteortus deposited two types of stone cells, dumbbell-shaped silica bodies with long bar between the semi rounded spheres a distinct, moderately thin shaft form and Narrow elliptical ractangular. The dumbbell shaped silica bodies are found one row over the vascular bundle. The spheres of the dumbbell may be semi rounded where they fit against the cells in the same row and they are distantly placed. Narrow elliptical ractangular shaped silica bodies are found in different position of the epidermal cell of the leaf (Fig.8). Paspalidium flavidum two types of stone cells were observed i.e bilobate with very short bar between squared lobes and a distinct, moderately thin shaft form and narrow elliptical rectangular.The bilobate shaped silica bodies are found one row over the vascular bundle, they fit against the cells in the same row and they are closely placed. Narrow elliptical rectangular bodies are found in different position of the epidermal cell of the leaf (Fig.19). Four types of stone cells were observed in Saccharum officinarum. These are bilobate with short bar between squared sphere, saddle wide rectangular, elongated sinuous and narrow elliptical rectangular. The dumbbell shaped and elongateded sinuous shaped silica bodies are found one row over the vascular bundle. The spheres of the dumbbell may be squared where they fit against the cells in the same row and they are distantly placed. Saddle shaped and narroe rectangular shaped silica bodies are found in different position of the epidermal cell of the leaf (Fig. 10).
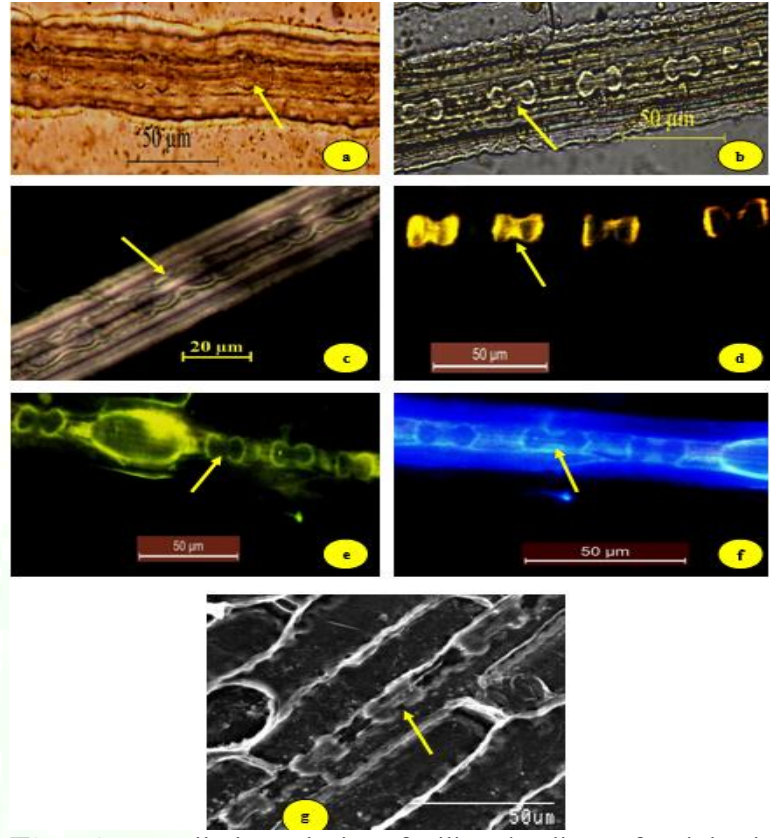

Fig. 6: Detailed analysis of silica bodies of Digitaria ciliaris under Light Microscope (a,b), Polarized Microscope (c), Fluroscence Microscope (d,e,f) and Scanning Electron Microscope (g).
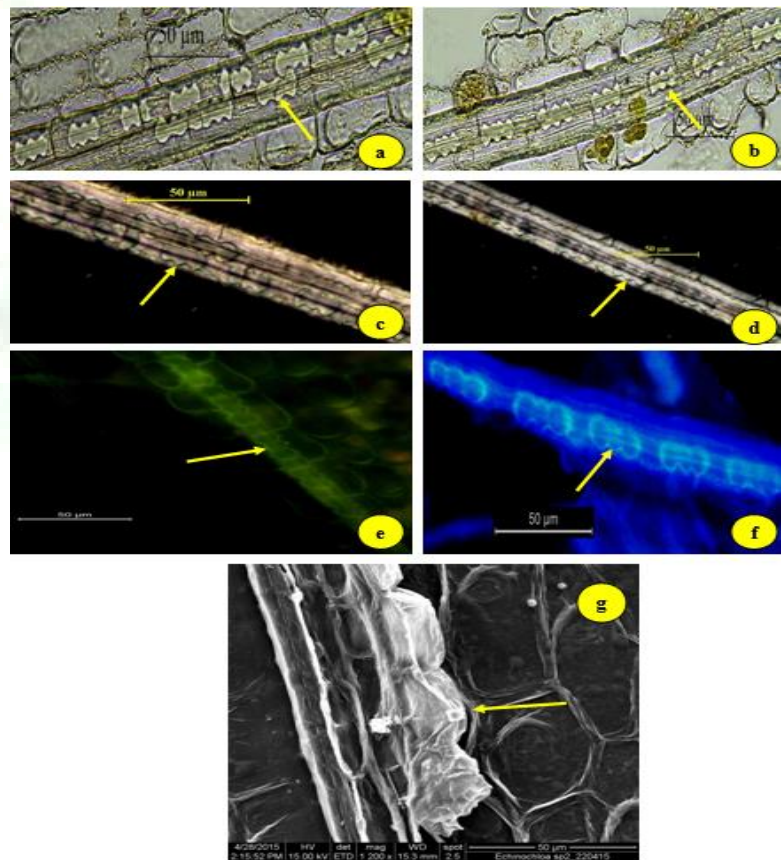

Fig. 7: Detailed analysis of silica bodies of Echinochloa colonum under Light Microscope (a,b), Polarized Microscope (c,d), Fluroscence Microscope (e,f) and Scanning Electron Microscope (g). 

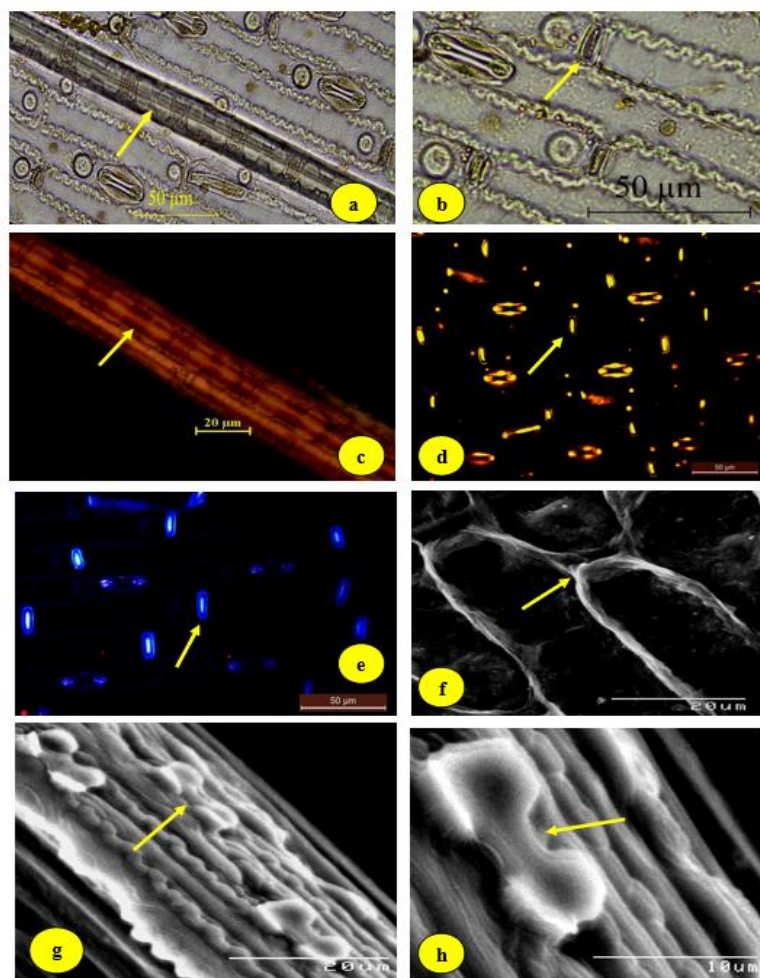

Fig.- 8

Fig. 8: Detailed analysis of silica bodies of Heteropogon contortus under Light Microscope (a,b), Polarized Microscope (c), Fluroscence Microscope (d,e) and Scanning Electron Microscope (f,g,h).
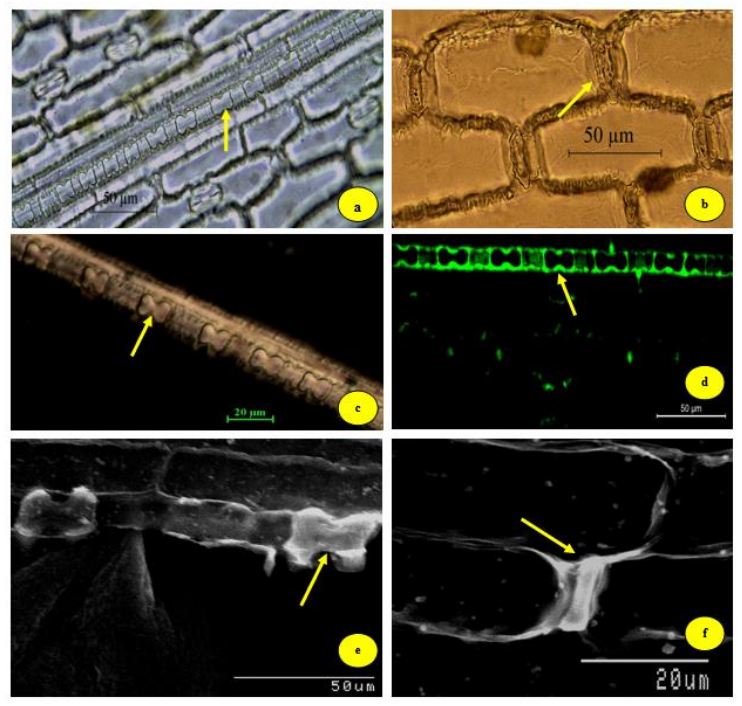

Fig. -9

Fig. 9: Detailed analysis of silica bodies of Paspalidium flavidum under Light Microscope (a,b), Polarized Microscope (d), Fluroscence Microscope (c) and Scanning Electron Microscope (e,f).

The qualitative and quantitative micro-morphological features of stone cells of the selected taxa are summarized in tables which include measurements and statistical analysis (Origin 6.1) including length and breadth of different types of stone cells [Table. I $(\mathbf{A}, \mathbf{B})]$. The investigated 5 species belonging to the sub- family Panicoideae, were found to form clusters the in dendrogram which from clusters depending upon micromorphological characters of stone cells. The dendrogram constracted through similarity matrix using UPGMA (Unweighted Pair Groups Method with Arithmetic average) divided the investigated species into three clusters.
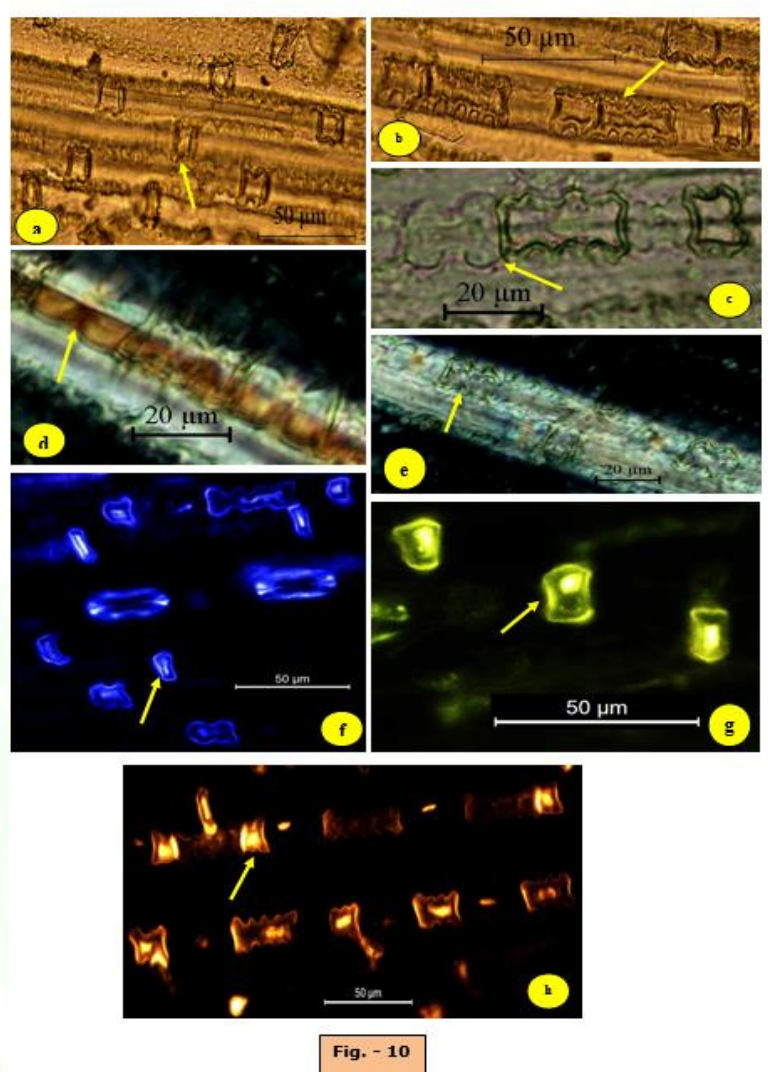

Fig.10: Detailed analysis of silica bodies of Saccharum officinarum under Light Microscope $(a, b, c)$, Polarized Microscope (d,e) and Fluroscence Microscope (f,g,h).

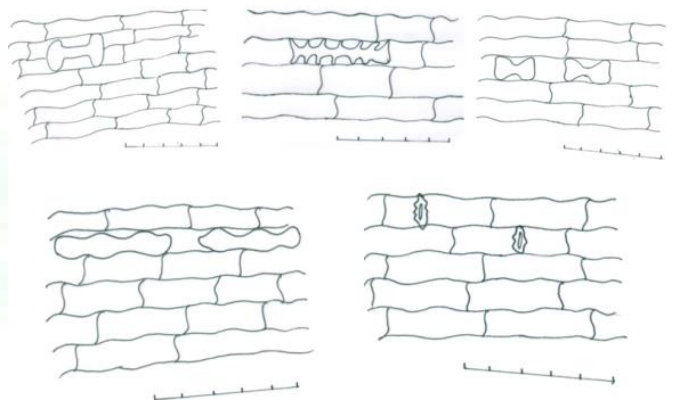

Fig. 11: Camera leucida drawing of five types of Silica bodies.

Cluster-1 consist of two species Digitaria ciliaris and Echinochloa colonum as they are very close due to presence of similar type of silica bodies i.e bilobate shaped and cluster-2 consist of Heteropogon contortus and Paspalidium flavidum because they both have two types and narrow elliptical shaped silica bodies. Saccharum officinarum placed singly due to presence of four types of silica bodies which are distantly related from other 4 plant species but it is related with Heteropogon contortus and Paspalidium 
flavidum than Digitaria ciliaris and Echinochloa colonum (Fig.12).

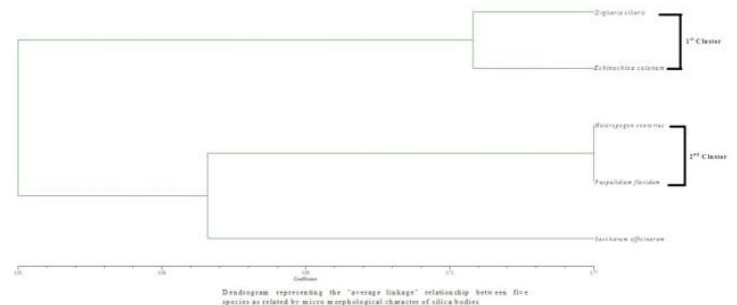

Fig.12: Dendrogram showing co-relation among the 5 species under the sub-family Panicoideae on the basis of micro-morphological character of silica bodies.

\section{Discussion}

Silica bodies are deposited in the cells of the dermal, vascular and fundamental tissue of the plant. Leaf epidermis may have contained a general assortment of bilobate dumbel shaped, rectangular, cross shaped, saddle shaped etc. The leaf part of plant species have silica bodies in varying amount. The five taxa under the sub-family Panicoideae mainly posses five types of Silica bodies (Fig.11). In some species two [Papalidium flavidum (Fig.9)] or four types [Sacharum officinarum (Fig.10)] of silica bodies are found. Maximum types of silica bodies are found over the vascular bundle, they fit against the cells in the same row or different row and some types of silica bodies are found in different position of epidermal cells which are scattered. Polylobate end rounded shaped silica bodies are found in Echinochloa colonum
(Fig.7), Bilobate shaped silica bodies are found in Heteropogon contortus and Digitaria ciliaris (Fig.8, 6) and Saddle wide Rectangular and Elongated sinuous shaped silica bodies are found Saccharum officinarum (Fig.10).
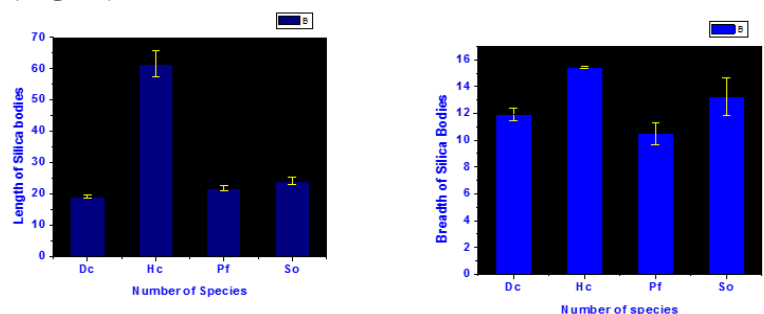

Fig: Graphical representation of bilobate shaped silica bodies [Length, Breadth]
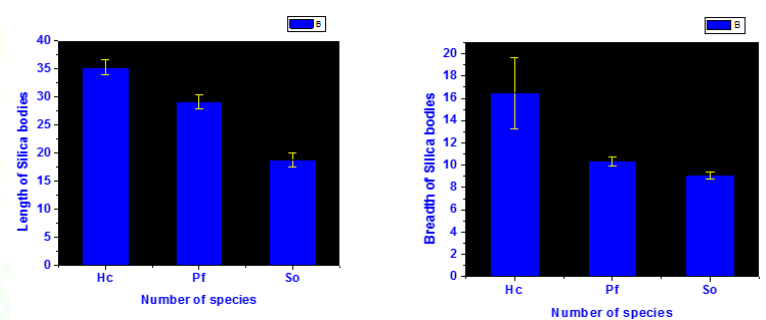

Fig.: Graphical representation of narrow elliptical shaped silica bodies [Length, Breadth]

Dc- Digitaria ciliaris, Hc- Heteropogon contortus, Pf - Paspalidium flavidum, So - Saccharum officinarum,

Table: Micro-morphological character indicated by 0,1 for dendogram analysis.

\begin{tabular}{cccccccccccccccccccc}
\hline S. No & Name of plant species & $\mathbf{1}$ & $\mathbf{2}$ & $\mathbf{3}$ & $\mathbf{4}$ & $\mathbf{5}$ & $\mathbf{6}$ & $\mathbf{7}$ & $\mathbf{8}$ & $\mathbf{9}$ & $\mathbf{1 0}$ & $\mathbf{1 1}$ & $\mathbf{1 2}$ & $\mathbf{1 3}$ & $\mathbf{1 4}$ & $\mathbf{1 5}$ & $\mathbf{1 6}$ & $\mathbf{1 7}$ & $\mathbf{1 8}$ \\
\hline 1. & Digitaria ciliaris & 1 & 0 & 0 & 1 & 1 & 0 & 0 & 0 & 0 & 1 & 0 & 1 & 0 & 1 & 0 & 1 & 0 & 0 \\
2. & Echinochloa colonum & 0 & 1 & 0 & 0 & 1 & 0 & 0 & 0 & 0 & 1 & 0 & 0 & 1 & 1 & 0 & 1 & 0 & 0 \\
3. & Heteropogon contortus & 1 & 0 & 1 & 0 & 1 & 0 & 1 & 0 & 0 & 1 & 1 & 1 & 0 & 1 & 0 & 0 & 1 & 0 \\
4. & Paspalidium flavidum & 1 & 0 & 0 & 1 & 0 & 1 & 1 & 0 & 0 & 1 & 1 & 1 & 0 & 1 & 0 & 0 & 1 & 0 \\
5. & Saccharum officinarum & 1 & 0 & 1 & 0 & 0 & 1 & 1 & 1 & 1 & 1 & 1 & 1 & 1 & 1 & 0 & 0 & 0 & 1 \\
\hline
\end{tabular}

1-Bilobate, 2- Polylobate, 3- long bar, 4- Short bar, 5- semi rounded, 6- Squared, 7- narrow elliptical rectangular, 8- Elongated sinuous, 9- Saddle wide rectangular, 10- presence of vascular bundle, 11- Scattered, 12- one row, 13- Two row, 14- Distantly arranged, 15- Closely arranged, 16- one type silica bodies, 17- Two types silica bodies, 18- Four types silica bodies

\section{Conclusion}

Analysis of silica bodies of the taxa from Paschim Medinipur district has revealed a large diversity in size and shapes. The stone cells show a great diversity and it can be used as diagnostic tool for identification. The shape, size, position, arrangement of stone cells are important taxonomic features. Dendogram representing the "average linkage" relationship within 5 species have found two clusters and shows close relationship between Paspalidium flavidum and Heteropogon contortus $(0.77 \%)$ [Table $-\mathrm{II}]$.

Table I (A): Quantitative and statistical analysis of Silica bodies (length) of the plant species.

\begin{tabular}{|c|c|c|c|c|c|c|c|c|}
\hline $\begin{array}{l}\text { Sl. } \\
\text { No }\end{array}$ & $\begin{array}{c}\text { Name of plant } \\
\text { species }\end{array}$ & $\begin{array}{c}\text { Types of Silica } \\
\text { bodies }\end{array}$ & $\begin{array}{l}\text { Length } \\
(\mu \mathrm{m})\end{array}$ & $\mathrm{SD}(\mathrm{yEr} \pm)$ & $\mathrm{SE}(\mathrm{yEr} \pm)$ & Min.(Y) & Max.(Y) & $\begin{array}{c}\text { Silica bodies } \\
\text { index }\end{array}$ \\
\hline 1. & Digitaria ciliaris & $\mathbf{A}$ & 19.23 & 1.45 & 0.54 & 16.88 & 21.3 & 7.21 \\
\hline 2. & Echinochloa colonum & B & 25.38 & 3.12 & 1.10 & 20.74 & 30.39 & 26.86 \\
\hline \multirow{2}{*}{3.} & \multirow{2}{*}{ Heteropogon contortus } & C & 61.49 & 8.42 & 4.21 & 51.39 & 71.31 & 24.07 \\
\hline & & D & 35.28 & 2.67 & 1.33 & 33.09 & 38.53 & 31.56 \\
\hline \multirow{2}{*}{4.} & \multirow{2}{*}{ Paspalidium flavidum } & $\mathbf{E}$ & 21.83 & 2.19 & 0.89 & 18.49 & 24.8 & 31.1 \\
\hline & & D & 29.09 & 3.52 & 1.24 & 24.11 & 35.83 & 31.16 \\
\hline \multirow{4}{*}{5.} & \multirow{4}{*}{ Saccharum officinarum } & $\mathbf{E}$ & 24.20 & 3.55 & 1.25 & 19.4 & 28.93 & 20.83 \\
\hline & & $\mathbf{F}$ & 18.23 & 4.62 & 2.31 & 11.93 & 23.05 & 31.15 \\
\hline & & $\mathbf{D}$ & 18.78 & 3.63 & 1.28 & 13.13 & 23.35 & 25.62 \\
\hline & & G & 33.73 & 5.26 & 2.63 & 28.81 & 41.13 & 16.66 \\
\hline
\end{tabular}

$\mathbf{A}=$ Bilobate with short bar between semi rounded sphere, $\mathbf{B}=$ Polylobate end rounded, $\mathbf{C}=$ Bilobate with long bar between semi rounded sphere, $\mathbf{D}=$ Narrow elliptical Rectangular, $\mathbf{E}=$ Bilobate with short bar between squared sphere, $\mathbf{F}=$ Saddle wide Rectangular, $\mathbf{G}=$ Elongated sinuous 
Table I (B): Quantitative and statistical analysis of Silica bodies (breadth) of the plant species.

\begin{tabular}{|c|c|c|c|c|c|c|c|}
\hline $\begin{array}{l}\text { S. } \\
\text { No }\end{array}$ & $\begin{array}{c}\text { Name of plant } \\
\text { species }\end{array}$ & $\begin{array}{c}\text { Types of } \\
\text { Silica bodies }\end{array}$ & Length $(\mu \mathrm{m})$ & $\mathrm{SD}(\mathrm{yEr} \pm)$ & $\operatorname{SE}(y E r \pm)$ & Min.(Y) & Max.(Y) \\
\hline 1. & Digitaria ciliaris & $\mathrm{A}$ & 11.94 & 1.33 & 0.47 & 10.7 & 14.84 \\
\hline 2. & Echinochloa colonum & B & 9.40 & 1.23 & 0.43 & 7.27 & 10.7 \\
\hline \multirow{2}{*}{3.} & \multirow{2}{*}{ Heteropogon contortus } & $\mathrm{C}$ & 15.46 & 0.14 & 0.08 & 15.31 & 15.59 \\
\hline & & $\mathrm{D}$ & 16.49 & 6.39 & 3.19 & 7.69 & 22.09 \\
\hline \multirow{2}{*}{4.} & \multirow{2}{*}{ Paspalidium flavidum } & $\mathrm{E}$ & 10.48 & 2.08 & 0.85 & 8.65 & 14.14 \\
\hline & & $\mathrm{D}$ & 10.37 & 1.06 & 0.40 & 8.88 & 12.1 \\
\hline \multirow{4}{*}{5.} & \multirow{4}{*}{ Saccharum officinarum } & $\mathrm{E}$ & 13.21 & 3.99 & 1.41 & 9.02 & 18.76 \\
\hline & & $\mathrm{F}$ & 12.95 & 2.24 & 1.12 & 10.64 & 15.3 \\
\hline & & $\mathrm{D}$ & 9.08 & 1.01 & 0.35 & 7.56 & 10.64 \\
\hline & & G & 13.33 & 1.76 & 0.88 & 11.8 & 15.88 \\
\hline
\end{tabular}

$\mathbf{A}=$ Bilobate with short bar between semi rounded sphere, $\mathbf{B}=$ Polylobate end rounded, $\mathbf{C}=$ Bilobate with long bar between semi rounded sphere, $\mathbf{D}=$ Narrow elliptical Rectangular, $\mathbf{E}=$ Bilobate with short bar between squared sphere, $\mathbf{F}=$ Saddle wide Rectangular, $\mathbf{G}=$ Elongated sinuous

Table II: Pairing affinity values of the five investigated taxa based on micro-morphological attributes of silica bodies of the sub-family Panicoideae.

\begin{tabular}{lccccc}
\hline $\begin{array}{c}\text { Name of plant } \\
\text { species }\end{array}$ & $\begin{array}{c}\text { Digitaria } \\
\text { ciliaris }\end{array}$ & $\begin{array}{c}\text { Echinochloa } \\
\text { colonum }\end{array}$ & $\begin{array}{c}\text { Heteropogon } \\
\text { contortus }\end{array}$ & $\begin{array}{c}\text { Paspalidium } \\
\text { flavidum }\end{array}$ & $\begin{array}{c}\text { Sacharum } \\
\text { officinarum }\end{array}$ \\
\hline Digitaria ciliaris & $\mathbf{1}$ & & & & \\
Echinochloa colonum & 0.72 & $\mathbf{1}$ & $\mathbf{1}$ & $\mathbf{1}$ \\
Heteropogon contortus & 0.66 & 0.50 & 0.77 & 0.61 \\
Paspalidium flavidum & 0.66 & 0.38 & 0.61 & $\mathbf{1}$ \\
Saccharum officinarum & 0.38 & 0.61 & & \\
\hline
\end{tabular}

\section{Acknowledgement}

I am highly acknowledge to UGC-DRS-SAP, New Delhi for their financial support in the form of Research Project and also thankful my sincere veneration and constant help to my supervisor Prof. Amal Kumar Mondal, FLS, FIAAT, Professor of Botany and Coordinator of the program, and also thanks to all of the research scholars specially thanks to Debasree Ghosh, Dr. Sk Md Abu Imam Saadi, Sayantan Tripathi, of the Plant Taxonomy, Biosystematic and Molecular Taxonomy Laboratory; UGC-DRS-SAP Department, Department of Botany \& Forestry, Vidyasagar University, Midnapore-721102, West Bengal, India. I am also grateful to Technical staffs of an University Science Instrumentation Centre (USIC), Vidyasagar University as well as Burdwan University and Bose Institute Kolkata.

\section{References}

1. Bienfait, H.F. "Importance des verrues foliaries silicifies dans la systématique des Selaginella: Observation en microscopic electronic á balayage (MEB)". Bull.jard. Bot. Belg. 55 (1985): 73-81.Online.

2. Goldblatt, P., Henrich, J.E. and Rudall P. "Occurrence of crystals in Iridaceae and allied families and their phylogenetic significance". Ann. Missouri Bot. Gard. 71 (1984): 1013-1020.Printed.

3. Jiang, X.M. and Zhou, Y. "SEM observation on crystals and silica in wood species of Chinese Gymnospermae". Acta Bot. Sin. 31(1989): 835840. Online.

4. Kaufman, P.B., Bigelow, W.C., Schmid, R. and Ghosheh, N.S. "Electron microprobe analysis of silica in epidermal cells Equisetum". Amer. J. Bot. 58 (1971): 309-316.Online.
5. Keating, R.C. "Anatomy of the monocotyledons, Acoraceae and Araceae". 9 ${ }^{\text {th }}$ edn. Oxford: (2003): Clarendon Press. Printed.

6. Laroche, J. “Contribution á l'étude de l'Equisetum arvense L. III: Recherches sur la nature et la localization de la silice chez le sporophyte." Rev. Gén. Bot. 75 (1968): 65-116. Online

7. Le, C. C., Guervin, C., Laroche, J. and Robert, D. "Modalites d'exerétion de la silice chez deux Ptéridophytes." Bull. Soc. Bot. (1991): 231-234. Online.

8. Piperno, D.R. "Phytolith analysis: An archaeological and geological prespective." San Diego, (1988): Academic press. Printed.

9. Piperno, D.R. "The occurrence of phytoliths in the reproductive structures of selected tropical angiosperms and their significance in tropical paleoecology, paleoethnobotany and systematic." Rev. Palaeobot. Palynol. 61 (1989): 147-173. Online.

10. Prychid, C.J. and Rudall, P.J. "Calcium oxalate crystals in Monocotyledons: A review of their structure and systematic." Ann. Bot. 84 (1999): 725739. Online.

11. Prychid, C.J. and Rudall, P.J. "Distribution of calcium oxalate crystals in monocotyledons. in Monocots". Systematics and Evolution of Proceedings of the Second International Conference on the Comparative Biology of the Monocots, Sydney. Eds Wilson, K.L., Morrison D.A. CSIRO: Melbourne. (2000): 159-162. Printed.

12. Rolleri, C., Deferrari, A.M. and Ciciarelli M. "Epidermis y estomatogenesis en Marattiaceae 
(Marattiales-Eusporangiopsida)." Revista Mus. La Plata, n.s., 14. Bot. 94 (1987) 129-147. Online.

13. Rudall, P.J. "Anatomy and systematic of Iridaceae." Bot. J. Linn. Soc. 114 (1994) 1-21. Online.

14. Sangster, A. G., Williams, S. E. and Hodson, M. J. Silica deposition in the needles of the Gymnosperms, 2: Scanning electron microscopy and x-ray microanalysis. in A. Pinilla. J. Juan-Tresserras \& M. J. Machado (eds.), Estado actual de los studios de fitolitos en suelosy plantas. Monografias del Centro de Ciencias Medioambientales, 4. Connsejo Superior de Investigaciones Cientificas and Centro de
Ciencias Medioambientales, Madrid. 1997, 135-145. Printed.

Cite this article as:

Shilpa Dinda, Souradut Ray and Amal kumar Mondal. Micro-morphological and morphometric characters analysis of Silica Bodies (SB) on leaf epidermal cells of five selected taxa in the Sub-family panicoideae based on Analytical Microscopy (AM): A systematic approach. Annals of Plant Sciences 6.01 (2017): 1504-1511.

DOI: http://dx.doi.org/10.21746/aps.2017.01.004

Source of support: UGC-DRS-SAP, New Delhi, India.

Conflict of interest: Nil 